\title{
CORRECTION
}

\section{Correction to: Gabapentinoid Benefit and Risk Stratification: Mechanisms Over Myth}

Heath McAnally (D) - Udo Bonnet - Alan D. Kaye

Published online: December 4, 2020

(C) The Author(s) 2020

Correction to: Pain Ther (2020) 9:441-452

https://doi.org/10.1007/s40122-020-00189-x

One of the authors has noticed that their affiliation was incorrect in the original publication. The affiliations for author, Udo Bonnet should be:

1. Department of Psychiatry, Psychotherapy and Psychosomatic Medicine, Evangelisches Krankenhaus Castrop-Rauxel, Academic Teaching Hospital of the University of DuisburgEssen, Castrop-Rauxel, Germany

And

2. Department of Psychiatry and Psy-

The original article can be found online at https://doi. org/10.1007/s40122-020-00189-x.

H. McAnally ( $\square)$

Northern Anesthesia and Pain Medicine, LLC, Eagle River, AK, USA

e-mail: hmcan@uw.edu

H. McAnally

Department of Anesthesiology and Pain Medicine,

University of Washington School of Medicine,

Seattle, WA, USA

chotherapy, Faculty of Medicine, LVR-Hospital Essen, University of Duisburg-Essen, Essen, Germany

Open Access. This article is licensed under a Creative Commons Attribution-NonCommercial 4.0 International License, which permits any non-commercial use, sharing, adaptation, distribution and reproduction in any medium or format, as long as you give appropriate credit to the original author(s) and the source, provide a link to the Creative Commons licence, and indicate if changes were made. The images or other third party material in this article are included in the article's Creative Commons licence, unless indicated otherwise in a credit line to the material. If material is not included in the article's Creative Commons licence and your intended use is not

\section{U. Bonnet}

Department of Psychiatry and Psychotherapy, Faculty of Medicine, LVR-Hospital Essen, University of Duisburg-Essen, Essen, Germany

\section{A. D. Kaye}

Department of Anesthesiology, Louisiana State University Health Sciences Center, Shreveport, LA, USA

\section{U. Bonnet}

Department of Psychiatry, Psychotherapy and Psychosomatic Medicine, Evangelisches

Krankenhaus Castrop-Rauxel, Academic Teaching

Hospital of the University of Duisburg-Essen,

Castrop-Rauxel, Germany 
permitted by statutory regulation or exceeds the permitted use, you will need to obtain permission directly from the copyright holder. To view a copy of this licence, visit http:// creativecommons.org/licenses/by-nc/4.0/. 